\title{
The Role of Protease-Activated Receptor Type 2 in Nociceptive Signaling and Pain
}

\section{P. MROZKOVA ${ }^{1,2}$, J. PALECEK ${ }^{1}$, D. SPICAROVA ${ }^{1}$}

${ }^{1}$ Department of Functional Morphology, Institute of Physiology of the Czech Academy of Sciences, Prague, Czech Republic, ${ }^{2}$ Department of Physiology, Faculty of Science, Charles University in Prague, Czech Republic

Received December 1, 2015

Accepted December 22, 2015

On-line April 12, 2016

\section{Summary}

Protease-activated receptors (PARs) belong to the G-proteincoupled receptor family, that are expressed in many body tissues especially in different epithelial cells, mast cells and also in neurons and astrocytes. PARs play different physiological roles according to the location of their expression. Increased evidence supports the importance of PARs activation during nociceptive signaling and in the development of chronic pain states. This short review focuses on the role of PAR2 receptors in nociceptive transmission with the emphasis on the modulation at the spinal cord level. PAR2 are cleaved and subsequently activated by endogenous proteases such as tryptase and trypsin. In vivo, peripheral and intrathecal administration of PAR2 agonists induces thermal and mechanical hypersensitivity that is thought to be mediated by PAR2-induced release of pronociceptive neuropeptides and modulation of different receptors. PAR2 activation leads also to sensitization of transient receptor potential channels (TRP) that are crucial for nociceptive signaling and modulation. PAR2 receptors may play an important modulatory role in the development and maintenance of different pathological pain states and could represent a potential target for new analgesic treatments.

\section{Key words}

Protease-activated receptor (PAR2) - Signaling pathways • Nociception • Pain • Spinal cord

\section{Corresponding author}

D. Spicarova, Department of Functional Morphology, Institute

of Physiology of the Czech Academy of Sciences,
Videnska 1083, 14220 Prague 4, Czech Republic. E-mail: dianaspicarova@biomed.cas.cz

\section{Introduction}

Extracellular proteases such as thrombin, trypsin, serin protease 1 and coagulation factors VII and Xa can regulate target cells by cleaving and activating receptors that belong to a family of G-protein-coupled protease-activated receptors (PARs) (Brass and Molino 1997, Corvera et al. 1997, Molino et al. 1997, Camerer et al. 2000, Vergnolle 2000). This receptor family has at least four members (PAR1-4). Mechanism of receptor triggering involves proteolytic unmasking of a cryptic $\mathrm{N}$-terminal sequence on the extracellular membrane that acts as a tethered receptor-activating ligand. In general, several proteases can activate a single PAR by cleaving it at specific site and exposing the tethered ligand domain. For example, trypsin, tryptase, coagulation factors VIIa and Xa and certain membrane-anchored proteases can all cleave and activate PAR2, although with varying potencies (Cenac et al. 2003, Chen et al. 2011, Rothmeier and Ruf 2012).

There are short specific synthetic peptides, based on the tethered ligand sequences, designed as PARs 1,2 and 4 agonists (Brass and Molino 1997). Some authors consider PAR3 as a co-factor for the activation of other PARs and it has no selective activating peptide (Noorbakhsh et al. 2003, Zhao et al. 2014). These synthetic peptides have been shown to activate the 
specific receptors and mimic the effects of the activating proteases for example SLIGKV-NH $\mathrm{N}_{2}$ and 2-furoylLIGRLO-NH $\mathrm{N}_{2}$ are frequently used for PAR2 activation. Due to these selective peptides, the physiological consequences of activating different PARs may be studied and distinguished accurately (Hollenberg et al. 1997, Kawabata et al. 1999). For the purpose of research there were also developed compounds which are able to act as antagonist, e.g. FSLLRY-NH $\mathrm{N}_{2}$ and GB83 inhibit PAR2.

PARs are present in most body tissues, with the highest expression in the epithelium (lungs, liver, digestive tract, skin, blood vessels) and they are also present in the peripheral and central nervous system (Dery et al. 1998, Vergnolle et al. 2001b, Hollenberg and Compton 2002). The physiological effect of their activation varies in different tissues.

PAR2 receptors are known to play an important role in the response of the organism to tissue injury, notably in the process of inflammation and repair (Dery et al. 1998). In particular, agonists of PAR2, tryptase and trypsin released from different cell types including mast cells, have widespread proinflammatory effects in part via a neurogenic mechanism (Saifeddine et al. 1996, Vergnolle et al. 1999, Steinhoff et al. 2000, Seeliger et al. 2003). PAR2 are expressed on a subset of primary sensory neurons and PAR2 agonists stimulate release of substance P (SP) and calcitonin gene-related peptide (CGRP) in peripheral tissues via activation of peripheral nerve endings (Steinhoff et al. 2000). It was also reported that PAR2 activation can sensitize adult rat dorsal root ganglion (DRG) neurons in vitro (Steinhoff et al. 2000). Intraplantar injection of subinflammatory doses of PAR2 agonists in rat and mice induced thermal and mechanical hyperalgesia and elevated Fos protein expression in the spinal cord (Vergnolle et al. 2001a). All these changes indicate an important role for PAR2 in nociceptive transmission.

This review focuses on the function of PAR2 in the nervous system, particularly in connection with transmission and modulation of nociceptive stimuli at the spinal cord level and pain perception.

\section{Mechanisms of PAR2 activation and intracellular signal transduction}

PARs are G-protein-coupled receptors (GPCRs), a family of receptors with large seven-transmembrane helical domain protein that sense molecules outside the cell and activate intracellular signaling pathways (Nystedt et al. 1994, Hoogerwerf et al. 2001, Macfarlane et al. 2001). Thrombin and trypsin are usually regarded as the main activators of PARs. PAR2 is a target for trypsin and other serine proteases, such as mast-cell tryptase, but it is not activated by thrombin (Nystedt et al. 1995, 1996, Molino et al. 1997). PAR2 lacks a hirudin-like thrombinbinding domain, but trypsin cleavage site was detected in its extracellular N-terminus domain (Nystedt et al. 1995). PAR2 is activated by proteolytic cleavage of its extracellular amino-terminus (Hollenberg et al. 1997, Steinhoff et al. 2000). These receptors can be also activated by exogenous proteases, as well as nonproteolytically by exogenous peptide sequences that mimic the final amino acids of the tethered ligand (Hollenberg et al. 1997, Al-Ani et al. 1999).

The signaling pathways that are triggered by PAR2 activation through the binding to activation molecules on G-proteins (Gq/11, Gi/o) may activate several signaling pathways including phospholipases, Jun N-terminal kinase and p44/42 mitogen-activated protein kinase (MAPK), ERK1/2, phosphatidylinositol 3-kinase (PI3K), adenylate cyclase (AC), protein kinase $\mathrm{C}$ (PKC), protein kinase A (PKA) and members of the SRC-family of tyrosine kinases (Kanke et al. 2001, Suen et al. 2010, 2014, Chen et al. 2011, Bao et al. 2015). These signaling pathways can affect various cellular activities - proliferation, gene transcription, morphological changes, motility and survival (Macfarlane et al. 2001, Kawabata et al. 2004). PAR2 activation was also reported to result in up/down-regulation of about 2500 genes that are important mainly for cell metabolism (around 1000 genes), cell cycle, complement and MAPK pathway, sirtuin enzymes, histone deacetylases and inflammatory cytokines (Suen et al. 2010).

\section{Expression of PAR2 in the nervous system}

High density expression of PAR2 receptors was documented in neurons of hippocampus, cortex, amygdala, thalamus, hypothalamus, striatum and in DRG neurons in rats (Striggow et al. 2001). All four PARs were also present in astrocyte culture from rat brain (Wang et al. 2002). PAR2 are expressed on neurons and astrocytes also in human CNS (D'Andrea et al. 1998, Noorbakhsh et al. 2006). Localization on guinea-pig myenteric and submucosal neurons was demonstrated earlier (Corvera et al. 1999). For the presence of PAR2 in the spinal cord dorsal horn exist mainly functional 
electrophysiological evidence (Alier et al. 2008, Fujita et al. 2009, Huang et al. 2011), while recently PAR2 were detected also using western blot analysis in the rat spinal cord tissue (Chen et al. 2015). PAR2 were immunohistochemically detected in many small-sized and some medium- to large-sized DRG neurons (Steinhoff et al. 2000, Dai et al. 2004). Significant population of small DRG neurons expressing TRPV1 receptors also showed expression of PAR2 (Amadesi et al. 2004, Dai et al. 2004), suggesting possible interactions between them.

\section{Activation of PAR2 in neuronal tissue}

Trypsin and tryptase are known as the main PAR2-activating proteases. Potentially, the main source of tryptase to activate neural PAR2 are mast cells that have been found in the choroid plexus, in the parenchymal and perivascular areas in the CNS and in close contact with peripheral nerves (Stead et al. 1987). Mast cell tryptase, although being less potent than trypsin, can regulate neuronal activity by cleaving PAR2 (Steinhoff et al. 2000, Reed et al. 2003) and other receptors. Selective PAR2 antagonist (FSLLRY-NH ${ }_{2}$ ) was able to block paclitaxel induced neuropathic pain that was accompanied by mast cell tryptase activity in spinal cord and DRG in mice (Chen et al. 2011). Tryptase is thus a strong candidate for neuronal PAR2 activation. There is a number of other possible PAR2 activators, such as $\mathrm{P} 22$, another trypsin-like serine protease with PAR2-activating capacity that has been detected in rat brain (Sawada et al. 2000). Precursors of trypsin (trypsinogen-IV, trypsinogen-III) and other PAR2 activators (factor $\mathrm{X}$ ) are also expressed in brain and human neural cell lines (Wiegand et al. 1993, Shikamoto and Morita 1999).

\section{The function of PAR2 in the nervous system}

All four PARs are expressed throughout the peripheral and central nervous system and were suggested to play many different roles in neurogenic inflammation, pain perception, pruritus sensation, nerve regeneration, secretory functions and $\mathrm{Ca}^{2+}$ mobilization (Corvera et al. 1999, de Garavilla et al. 2001, Linden et al. 2001, Noorbakhsh et al. 2003). The role of PAR2 on the peripheral terminals of nociceptive DRG neurons is relatively well known. They have been implicated in the activation and/or modulation of nociceptor function (Vergnolle et al. 2001a, Fiorucci and Distrutti 2002,
Cenac and Vergnolle 2005). The peripheral nerve endings may be activated by proteases which are generated and released during tissue trauma and inflammation. Increased PAR2 immunoreactivity has been reported on primary afferent nerve fibers in the skin of patients with atopic dermatitis. Intracutaneous injection of a PAR2 agonist provoked an itch response in these patients (Steinhoff et al. 2003).

PAR2 agonists induced and prolonged hyperexcitability of guinea-pig submucosal neurons (Reed et al. 2003). PAR2 activation rapidly increased cytosolic concentration of $\mathrm{Ca}^{2+}$ from intracellular stores, whereas sustained $\mathrm{Ca}^{2+}$ elevation was dependent on the influx from extracellular space in adult rat DRG neurons in vitro (Steinhoff et al. 2000). Over $60 \%$ of DRG neurons coexpressed PAR2 with SP and CGRP, and PAR2 agonists stimulated the release of these peptides in peripheral tissues and in the spinal cord (Steinhoff et al. 2000). The release of these neuropeptides is important for nociceptive transmission. Intraplantar administration of subinflammatory doses of PAR2 agonists enhanced and prolonged hyperalgesia and induced activation of secondorder nociceptive neurons at the spinal cord level in rodents. Also experiments in PAR2-deficient mice proved that PAR2 activation significantly contributes to inflammatory hyperalgesia (Vergnolle et al. 2001a).

Activation of PAR2 receptors triggers several intracellular signaling cascades, one of them is associated with G-protein and $\mathrm{PLC} / \mathrm{Ca}^{2+} / \mathrm{PKC}$ signaling pathway (Bohm et al. 1996, Seatter et al. 2004) and another one is associated with $\beta$-arrestin including MAPK (ERK1/2) signaling (DeFea et al. 2000, Rothmeier and Ruf 2012). Activation of PKC may lead to the activation and nuclear translocation of NF- $\mathrm{KB}$ in neurons (Lilienbaum and Israel 2003). Activation of NF-kB-mediated signaling increased the histone acetylation and facilitated the expression of BDNF in the central neurons (Peng et al. 2011). Some groups observed that activation of PAR2 signaling was required for the inflammation induced BDNF release from microglia (Yuan et al. 2010, Fan et al. 2014).

\section{The role of PAR2 at the spinal cord level}

Although PAR2 are known to be expressed on neurons and astrocytes in rodent and human CNS (Noorbakhsh et al. 2006), their expression in the spinal cord was not proved by immunohistochemical methods (Alier et al. 2008). However, functional studies on spinal cord slices suggested PAR2 presence on the central 
terminals of primary afferent nerve fibers and in dorsal horn neurons (Fujita et al. 2009, Huang et al. 2011). Very recently PAR2 were detected by western blot analysis in the superficial dorsal horn tissue (Chen et al. 2015).

PAR2 are colocalized with proinflammatory neuropeptides, such as substance P and CGRP, in DRG sensory neurons. Trypsin, tryptase and selective agonists of PAR2 stimulate the release of both CGRP and SP from $\mathrm{C}$-fibers in peripheral tissues and in the spinal cord (Steinhoff et al. 2000). Peripheral administration of trypsin, tryptase and PAR2-activating peptide caused SP and CGRP release from sensory nerves. It caused massive edema that could be prevented by NK1R and CGRP1 receptor inhibition (Steinhoff et al. 2000).

Further studies at spinal cord level demonstrated that intrathecal (i.t.) application of PAR2 agonist induced mechanical allodynia and thermal hyperalgesia in healthy animals and augmented increased sensitivity present in a peripheral inflammatory pain model (Alier et al. 2008, Huang et al. 2011). PAR2-induced hypersensitivity was mediated by PGE2 release via COX activation in the spinal cord (Koetzner et al. 2004). In a paclitaxel-induced neuropathic pain model, i.t. application of PAR2 antagonist reversed mechanical allodynia and heat hyperalgesia (Chen et al. 2011).

Electrophysiological study with whole-cell recordings from young rat substantia gelatinosa neurons, showed no increase in spontaneous excitatory postsynaptic current (sEPSC) frequency or neuronal excitability following application of synthetic PAR2 agonists or trypsin. Moreover, trypsin slightly decreased sEPSC frequency in the dorsal horn (Alier et al. 2008). In comparison, another study showed that PAR2 agonist significantly enhanced frequency of sEPSC in a similar preparations from adult rats, suggesting involvement of PAR2 receptors in modulation of nociceptive synaptic transmission at the spinal cord level (Fujita et al. 2009). Direct activation of PAR2 in the spinal cord was suggested also in a study demonstrating decrease of spontaneous inhibitory postsynaptic currents frequency and amplitude in substantia gelatinosa neurons, implicating that PAR2 activation in the spinal cord may potentiate nociception by affecting the inhibitory rather than the excitatory transmission in the spinal dorsal horn neurons (Huang et al. 2011).

Altogether, this published evidence suggests that PAR2 play an important role in the process of nociceptive transmission and in neurogenic inflammatory mechanisms both in the periphery and at the spinal cord level. The precise role and exact importance for spinal nociceptive modulation is not completely understood and needs further research.

\section{PAR2-induced activation of downstream protein kinases and other enzymes in neural tissue}

PAR2 are expressed in nociceptive DRG neurons (Dai et al. 2004) and colocalize with PKC and PKA, which are activated downstream of PAR2 receptors (Amadesi et al. 2006). The PKC activation cascade involves PAR2-induced activation of PLC leading to production of diacylglycerol and inositol 1,4,5trisphosphate, which increases intracellular concentration of $\mathrm{Ca}^{2+}$ and activates PKC (Mule et al. 2002). The PKA activation cascade involves PAR2-induced mobilization of cAMP (Amadesi et al. 2006).

A selective PAR2 agonist can induce phosphorylation and activation of PKD in cultured rat DRG neurons (Amadesi et al. 2009). DRG neurons express all three isoforms of PKD, PKD1 (also known as $\mathrm{PKC} \mu$ ), PKD2 and PKD3. PKDs are downstream targets of diacylglycerol (DAG) and PKCs, which may be induced by PAR2 activation (Amadesi et al. 2009). PKD1 directly interacts with TRPV1 in cell lines and primary sensory neurons, suggesting that PKD may regulate TRPV1 activity (Wang et al. 2004).

PAR2 activation leads to increased PLC activity and generation of IP3 and mobilization of $\mathrm{Ca}^{2+}$ in neurons and astrocytes (Rothmeier and Ruf 2012), which can result in PLA2 activation and increased production and release of arachidonic acid (AA), which is the substrate for cyclooxygenase (COX) (Poole et al. 2013). An increase in AA production leads also to increased synthesis and release of PGE that may increase intracellular cAMP through stimulation of AC. Subsequently these steps lead to neuronal hyperexcitability and hyperalgesia (Koetzner et al. 2004).

PAR2 agonists lead to activation of ERK1/2 MAP kinases in multiple ways. It is known that the ERK/MAPK activation can contribute to increased nociceptive responses in the dorsal horn and DRG neurons following inflammation or nerve injury ( $\mathrm{Ji}$ et al. 2009). Activation of PAR2 induces assembly of a MAPK signaling cascade by a mechanism that depends on $\beta$-arrestins (DeFea et al. 2000). Beta-arrestin dependent endocytosis of PAR2 is required for intracellular targeting of activated ERK1/2, which is retained in the 
cytosol instead of being translocated to the nucleus. The concentration of ERK1/2 in cytosol depends on the formation of a signaling complex that includes internalized PAR2, $\beta$-arrestin 1, Raf-1 and pERK1/2 (DeFea et al. 2000).

\section{Transient receptor potential channels sensitization}

PAR2 is highly co-expressed with TRPV1 receptors in the DRG neurons (Amadesi et al. 2004, Hoogerwerf et al. 2004). PAR2 activation leads to TRPV1 sensitization via PLC (Amadesi et al. 2004) and via two key kinases PKCE and PKA that phosporylate TRPV1 receptor (Amadesi et al. 2006, Spicarova and Palecek 2008). Sensitized TRPV1 receptor could be subsequently activated by endogenous agonists (Spicarova and Palecek 2009, Spicarova et al. 2014b). PAR2 activation enhanced TRPV1 agonist (capsaicin) stimulated neuropeptides (SP, CGRP) release within the spinal cord dorsal horn (Amadesi et al. 2004). In vivo, intraplantar injection of PAR2 agonist induced thermal hyperalgesia dependent on TRPV1 receptor activation (Amadesi et al. 2004). TRPV1 mediated DRG and spinal neurons activation in paclitaxel induced neuropathic pain (Li et al. 2015). It was also shown that spinal TRPV1 activation mediates chemokine CCL2- or plantar incision-induced hyperalgesia (Spicarova et al. 2014a, Uchytilova et al. 2014). Recently it was demonstrated that blocking of spinal PAR2 and TRPV1 receptors attenuated oxaliplatin-induced neuropathic pain and this effect was mediated by decreased release of SP and CGRP in the superficial dorsal horn of the spinal cord (Chen et al. 2015).

PAR2 co-expression in rat DRG neurons with TRPV4 receptors and neuropeptides SP and CGRP was also demonstrated (Grant et al. 2007, Poole et al. 2013). Activation of PAR2 sensitized TRPV4 receptors to agonist application due to PLC- $\beta$, PIP2, IP3, PLA, PKA, PKC and AA activation (Grant et al. 2007, Poole et al. 2013). These authors also showed that TRPV4 activation promoted SP and CGRP release from afferent nerves in the spinal cord and this process was enhanced by PAR2 agonist pretreatment. In vivo, intraplantar injection of PAR2 agonist resulted in mechanical hyperalgesia that was prevented in TRPV4 knock-out mice. The same PAR2 agonist treatment robustly enhanced hyperalgesia induced by the injection of TRPV4 agonist (Grant et al. 2007).
PAR2 is co-expressed with TRPA1 in small DRG neurons (Dai et al. 2007). TRPA1 receptors could be activated by chemical compounds occurring in mustard, wasabi, garlic, onion or cinnamon, they are potential sensors for noxious cold and the mechanosensitivity is also suggested (Hill and Schaefer 2007, Laursen et al. 2014). Electrophysiological studies have shown that PAR2 sensitizes TRPA1, and this effect can be blocked by a PLC inhibitor (Dai et al. 2007). Similarly it was shown that PAR2 activation of PKA and PLC also participate in TRPA1 mediated sensitization in nociceptive transmission (Wang et al. 2008). In vivo, it has been demonstrated that PAR2 mediates paclitaxelinduced mechanical, heat and cold hypersensitivity through the activation of TRPA1 (Chen et al. 2011).

\section{Role of PAR2 in inflammatory, neuropathic and cancer pain}

Critical involvement of PAR2 in the pathogenesis of several types of inflammatory or neuropathic pain was demonstrated previously (Bao et al. 2014). PAR2 signaling is involved in the sensitization of peripheral nociceptors and dorsal horn neurons in several pathological pain states (Dai et al. 2007, Grant et al. 2007, Chen et al. 2011).

PAR2 are present in many cells involved in inflammation, their activation provokes the release of numerous inflammatory mediators, such as prostaglandins, SP, CGRP or cytokines (interleukine-1 and TNF- $\alpha$ ), that in turn may induce or modulate pain perception (Steinhoff et al. 2000, Vergnolle et al. 2001a, Cenac et al. 2002). PAR2-deficient mice developed significantly less pronounced inflammatory hyperalgesia in response to intraplantar injection of formalin or the mast cell degranulator compound 48/80 (Vergnolle et al. 2001a). PAR2 agonist-mediated hyperalgesia was also dependent on a mechanism involving central activation of neurokinin-1 receptors, and release of prostaglandins (Vergnolle et al. 2001a).

Neuropathic pain often develops after peripheral and central nervous system injuries, local inflammation, diabetic neuropathy, viral infection, major surgeries, stroke and after chemotherapy application (Woolf and Mannion 1999, Ji and Strichartz 2004). In a chemotherapy (paclitaxel) induced model of neuropathic pain, increased mast cell tryptase activity was demonstrated on the periphery, in the DRG as well as in the spinal cord in mice (Chen et al. 2011). Intrathecal 
administration of PAR2 antagonist prevented paclitaxelinduced mechanical allodynia and thermal hyperalgesia and attenuated cold hypersensitivity, while it was also selectively blocked by systemic administration of TRPV1, TRPV4 and TRPA1 receptors antagonists. All these TRP receptors were also shown to be sensitized after PAR2 activation, probably due to the activation of PKC and PKA pathways (Chen et al. 2011). It was shown that PAR2 activation may mediate increased cAMP and PKA activity and cAMP-dependent neuronal hyperexcitability in a model of prolonged compression of DRG. The application of PAR2 antagonist resulted in blocking of the cAMP-PKA pathway activation, which contributes to the hyperalgesia (Huang et al. 2012).

Proteases and their receptors may be also involved in cancer pain, since carcinomas and associated inflammatory cells (mast cells) produce and secrete proteases during carcinogenesis. PAR2 activation was identified as a novel mechanism of cancer-dependent allodynia which was abolished by serine protease inhibition, diminished by mast cell depletion and it was absent in PAR2-deficient mice (Lam et al. 2012). Further the proportion of neurons that exhibited PAR2immunoreactivity was also increased in this model (Lam et al. 2012). It was suggested that serine protease inhibitors and PAR2 antagonists may be useful for treatment of cancer pain (Lam and Schmidt 2010).

In the model of bone cancer pain, induction and persistence of pain behavior correlated with tumor cell implantation and induced up-regulation of PAR2 in sciatic nerve and DRG. PAR2 knock-out or intrathecal administration of PAR2 antagonist prevented and in the same case reversed the bone cancer-related pain behavior and related neurochemical changes in the DRG and spinal cord dorsal horn (Liu et al. 2014). PAR2 was suggested to be an important mediator for peripheral sensitization of bone cancer pain and inhibiting PAR2 activation as a new therapeutic target in bone cancer pain development and therapy (Liu et al. 2014).

\section{Conclusion}

Pain is a complex, subjective phenomenon that involves participation of numerous receptors in different cells, tissues and organs. Protease-activated receptors type 2 are localized in many tissues and significant expression of these receptors was demonstrated in different parts of the peripheral and central nervous system. Recent evidence clearly demonstrated that PAR2 play an important role in the process of pain development, modulation and transmission. Endogenous activators, proteases such as trypsin and tryptase are considered as the major signaling molecules, which can regulate nociceptive transmission by PAR2 activation. PAR2 signaling was shown to have a significant impact on the induction and maintenance of persistent pain, especially in inflammatory, neuropathic and cancer pain. All this available information about the role of PAR2 in nociception and pain suggests that PAR2 may be an attractive target for the development of new options for pain treatment.

\section{Conflict of Interest}

There is no conflict of interest.

\section{Acknowledgements}

GAUK620312, LH12058, RVO67985823, P304/12/ G069, GACR15-11138S, LH15279, BIOCEV - Biotechnology and Biomedicine Centre of the Academy of Sciences and Charles University (CZ.1.05/1.1.00/ 02.0109), financed by the European Regional Development Fund.

\section{References}

AL-ANI B, SAIFEDDINE M, KAWABATA A, RENAUX B, MOKASHI S, HOLLENBERG MD: Proteinaseactivated receptor 2 (PAR(2)): development of a ligand-binding assay correlating with activation of PAR(2) by PAR(1)- and PAR(2)-derived peptide ligands. J Pharmacol Exp Ther 290: 753-760, 1999.

ALIER KA, ENDICOTT JA, STEMKOWSKI PL, CENAC N, CELLARS L, CHAPMAN K, ANDRADE-GORDON P, VERGNOLLE N, SMITH PA: Intrathecal administration of proteinase-activated receptor-2 agonists produces hyperalgesia by exciting the cell bodies of primary sensory neurons. J Pharmacol Exp Ther 324: 224-233, 2008.

AMADESI S, NIE J, VERGNOLLE N, COTTRELL GS, GRADY EF, TREVISANI M, MANNI C, GEPPETTI P, MCROBERTS JA, ENNES H, DAVIS JB, MAYER EA, BUNNETT NW: Protease-activated receptor 2 sensitizes the capsaicin receptor transient receptor potential vanilloid receptor 1 to induce hyperalgesia. J Neurosci 24: 4300-4312, 2004. 
AMADESI S, COTTRELL GS, DIVINO L, CHAPMAN K, GRADY EF, BAUTISTA F, KARANJIA R, BARAJASLOPEZ C, VANNER S, VERGNOLLE N, BUNNETT NW: Protease-activated receptor 2 sensitizes TRPV1 by protein kinase Cepsilon- and A-dependent mechanisms in rats and mice. J Physiol 575: 555-571, 2006.

AMADESI S, GRANT AD, COTTRELL GS, VAKSMAN N, POOLE DP, ROZENGURT E, BUNNETT NW: Protein kinase D isoforms are expressed in rat and mouse primary sensory neurons and are activated by agonists of protease-activated receptor 2. J Comp Neurol 516: 141-156, 2009.

BAO Y, HOU W, HUA B: Protease-activated receptor 2 signalling pathways: a role in pain processing. Expert Opin Ther Targets 18: 15-27, 2014.

BAO Y, GAO Y, HOU W, YANG L, KONG X, ZHENG H, LI C, HUA B: Engagement of signaling pathways of protease-activated receptor 2 and mu-opioid receptor in bone cancer pain and morphine tolerance. Int J Cancer 137: 1475-1483, 2015.

BOHM SK, KONG W, BROMME D, SMEEKENS SP, ANDERSON DC, CONNOLLY A, KAHN M, NELKEN NA, COUGHLIN SR, PAYAN DG, BUNNETT NW: Molecular cloning, expression and potential functions of the human proteinase-activated receptor-2. Biochem J 314: 1009-1016, 1996.

BRASS LF, MOLINO M: Protease-activated G protein-coupled receptors on human platelets and endothelial cells. Thromb Haemost 78: 234-241, 1997.

CAMERER E, HUANG W, COUGHLIN SR: Tissue factor- and factor X-dependent activation of protease-activated receptor 2 by factor VIIa. Proc Natl Acad Sci U S A 97: 5255-5260, 2000.

CENAC N, COELHO AM, NGUYEN C, COMPTON S, ANDRADE-GORDON P, MACNAUGHTON WK, WALLACE JL, HOLLENBERG MD, BUNNETT NW, GARCIA-VILLAR R, BUENO L, VERGNOLLE N: Induction of intestinal inflammation in mouse by activation of proteinase-activated receptor-2. Am J Pathol 161: 1903-1915, 2002.

CENAC N, GARCIA-VILLAR R, FERRIER L, LARAUCHE M, VERGNOLLE N, BUNNETT NW, COELHO AM, FIORAMONTI J, BUENO L: Proteinase-activated receptor-2-induced colonic inflammation in mice: possible involvement of afferent neurons, nitric oxide, and paracellular permeability. J Immunol 170: 4296-4300, 2003.

CENAC N, VERGNOLLE N: Proteases and protease-activated receptors (PARs): novel signals for pain. Curr Top Med Chem 5: 569-576, 2005.

CHEN K, ZHANG ZF, LIAO MF, YAO WL, WANG J, WANG XR: Blocking PAR2 attenuates oxaliplatin-induced neuropathic pain via TRPV1 and releases of substance P and CGRP in superficial dorsal horn of spinal cord. J Neurol Sci 352: 62-67, 2015.

CHEN Y, YANG C, WANG ZJ: Proteinase-activated receptor 2 sensitizes transient receptor potential vanilloid 1, transient receptor potential vanilloid 4 , and transient receptor potential ankyrin 1 in paclitaxel-induced neuropathic pain. Neuroscience 193: 440-451, 2011.

CORVERA CU, DERY O, MCCONALOGUE K, BOHM SK, KHITIN LM, CAUGHEY GH, PAYAN DG, BUNNETT NW: Mast cell tryptase regulates rat colonic myocytes through proteinase-activated receptor 2. J Clin Invest 100: 1383-1393, 1997.

CORVERA CU, DERY O, MCCONALOGUE K, GAMP P, THOMA M, AL-ANI B, CAUGHEY GH, HOLLENBERG MD, BUNNETT NW: Thrombin and mast cell tryptase regulate guinea-pig myenteric neurons through proteinase-activated receptors-1 and -2. J Physiol 517: 741-756, 1999.

D'ANDREA MR, DERIAN CK, LETURCQ D, BAKER SM, BRUNMARK A, LING P, DARROW AL, SANTULLI RJ, BRASS LF, ANDRADE-GORDON P: Characterization of protease-activated receptor-2 immunoreactivity in normal human tissues. J Histochem Cytochem 46: 157-164, 1998.

DAI Y, MORIYAMA T, HIGASHI T, TOGASHI K, KOBAYASHI K, YAMANAKA H, TOMINAGA M, NOGUCHI K: Proteinase-activated receptor 2-mediated potentiation of transient receptor potential vanilloid subfamily 1 activity reveals a mechanism for proteinase-induced inflammatory pain. J Neurosci 24: 4293-4299, 2004.

DAI Y, WANG S, TOMINAGA M, YAMAMOTO S, FUKUOKA T, HIGASHI T, KOBAYASHI K, OBATA K, YAMANAKA H, NOGUCHI K: Sensitization of TRPA1 by PAR2 contributes to the sensation of inflammatory pain. J Clin Invest 117: 1979-1987, 2007. 
DE GARAVILLA L, VERGNOLLE N, YOUNG SH, ENNES H, STEINHOFF M, OSSOVSKAYA VS, D'ANDREA MR, MAYER EA, WALLACE JL, HOLLENBERG MD, ANDRADE-GORDON P, BUNNETT NW: Agonists of proteinase-activated receptor 1 induce plasma extravasation by a neurogenic mechanism. $B r J$ Pharmacol 133: 975-987, 2001.

DEFEA KA, ZALEVSKY J, THOMA MS, DERY O, MULLINS RD, BUNNETT NW: beta-arrestin-dependent endocytosis of proteinase-activated receptor 2 is required for intracellular targeting of activated ERK1/2. J Cell Biol 148: 1267-1281, 2000.

DERY O, CORVERA CU, STEINHOFF M, BUNNETT NW: Proteinase-activated receptors: novel mechanisms of signaling by serine proteases. Am J Physiol 274: C1429-C1452, 1998.

FAN Y, CHEN J, YE J, YAN H, CAI Y: Proteinase-activated receptor 2 modulates corticotropin releasing hormoneinduced brain-derived neurotrophic factor release from microglial cells. Cell Biol Int 38: 92-96, 2014.

FIORUCCI S, DISTRUTTI E: Role of PAR2 in pain and inflammation. Trends Pharmacol Sci 23: 153-155, 2002.

FUJITA T, LIU T, NAKATSUKA T, KUMAMOTO E: Proteinase-activated receptor-1 activation presynaptically enhances spontaneous glutamatergic excitatory transmission in adult rat substantia gelatinosa neurons. J Neurophysiol 102: 312-319, 2009.

GRANT AD, COTTRELL GS, AMADESI S, TREVISANI M, NICOLETTI P, MATERAZZI S, ALTIER C, CENAC N, ZAMPONI GW, BAUTISTA-CRUZ F, LOPEZ CB, JOSEPH EK, LEVINE JD, LIEDTKE W, VANNER S, VERGNOLLE N, GEPPETTI P, BUNNETT NW: Protease-activated receptor 2 sensitizes the transient receptor potential vanilloid 4 ion channel to cause mechanical hyperalgesia in mice. $J$ Physiol 578: 715-733, 2007.

HILL K, SCHAEFER M: TRPA1 is differentially modulated by the amphipathic molecules trinitrophenol and chlorpromazine. J Biol Chem 282: 7145-7153, 2007.

HOLLENBERG MD, COMPTON SJ: International Union of Pharmacology. XXVIII. Proteinase-activated receptors. Pharmacol Rev 54: 203-217, 2002.

HOLLENBERG MD, SAIFEDDINE M, AL-ANI B, KAWABATA A: Proteinase-activated receptors: structural requirements for activity, receptor cross-reactivity, and receptor selectivity of receptor-activating peptides. Can J Physiol Pharmacol 75: 832-841, 1997.

HOOGERWERF WA, ZOU L, SHENOY M, SUN D, MICCI MA, LEE-HELLMICH H, XIAO SY, WINSTON JH, PASRICHA PJ: The proteinase-activated receptor 2 is involved in nociception. $J$ Neurosci 21: 9036-9042, 2001.

HOOGERWERF WA, SHENOY M, WINSTON JH, XIAO SY, HE Z, PASRICHA PJ: Trypsin mediates nociception via the proteinase-activated receptor 2: a potentially novel role in pancreatic pain. Gastroenterology 127: 883-891, 2004.

HUANG Z, TAO K, ZHU H, MIAO X, WANG Z, YU W, LU Z: Acute PAR2 activation reduces GABAergic inhibition in the spinal dorsal horn. Brain Res 1425: 20-26, 2011.

HUANG ZJ, LI HC, COWAN AA, LIU S, ZHANG YK, SONG XJ: Chronic compression or acute dissociation of dorsal root ganglion induces cAMP-dependent neuronal hyperexcitability through activation of PAR2. Pain 153: 1426-1437, 2012.

JI RR, STRICHARTZ G: Cell signaling and the genesis of neuropathic pain. Sci STKE 2004: reE14, 2004.

JI RR, GEREAU RWT, MALCANGIO M, STRICHARTZ GR: MAP kinase and pain. Brain Res Rev 60: 135-148, 2009.

KANKE T, MACFARLANE SR, SEATTER MJ, DAVENPORT E, PAUL A, MCKENZIE RC, PLEVIN R: Proteinase-activated receptor-2-mediated activation of stress-activated protein kinases and inhibitory kappa $\mathrm{B}$ kinases in NCTC 2544 keratinocytes. J Biol Chem 276: 31657-31666, 2001.

KAWABATA A, SAIFEDDINE M, AL-ANI B, LEBLOND L, HOLLENBERG MD: Evaluation of proteinaseactivated receptor-1 (PAR1) agonists and antagonists using a cultured cell receptor desensitization assay: activation of PAR2 by PAR1-targeted ligands. J Pharmacol Exp Ther 288: 358-370, 1999. 
KAWABATA A, KANKE T, YONEZAWA D, ISHIKI T, SAKA M, KABEYA M, SEKIGUCHI F, KUBO S, KURODA R, IWAKI M, KATSURA K, PLEVIN R: Potent and metabolically stable agonists for proteaseactivated receptor-2: evaluation of activity in multiple assay systems in vitro and in vivo. J Pharmacol Exp Ther 309: 1098-1107, 2004.

KOETZNER L, GREGORY JA, YAKSH TL: Intrathecal protease-activated receptor stimulation produces thermal hyperalgesia through spinal cyclooxygenase activity. J Pharmacol Exp Ther 311: 356-363, 2004.

LAM DK, SCHMIDT BL: Serine proteases and protease-activated receptor 2-dependent allodynia: a novel cancer pain pathway. Pain 149: 263-272, 2010.

LAM DK, DANG D, ZHANG J, DOLAN JC, SCHMIDT BL: Novel animal models of acute and chronic cancer pain: a pivotal role for PAR2. J Neurosci 32: 14178-14183, 2012.

LAURSEN WJ, BAGRIANTSEV SN, GRACHEVA EO: TRPA1 channels: chemical and temperature sensitivity. Curr Top Membr 74: 89-112, 2014.

LI Y, ADAMEK P, ZHANG H, TATSUI CE, RHINES LD, MROZKOVA P, LI Q, KOSTURAKIS AK, CASSIDY RM, HARRISON DS, CATA JP, SAPIRE K, KENNAMER-CHAPMAN RM, JAWAD AB, GHETTI A, YAN J, PALECEK J, DOUGHERTY PM: The cancer chemotherapeutic paclitaxel increases human and rodent sensory neuron responses to TRPV1 by activation of TLR4. J Neurosci 35: 13487-13500, 2015.

LILIENBAUM A, ISRAEL A: From calcium to NF-kappa B signaling pathways in neurons. Mol Cell Biol 23: 26802698, 2003.

LINDEN DR, MANNING BP, BUNNETT NW, MAWE GM: Agonists of proteinase-activated receptor 2 excite guinea pig ileal myenteric neurons. Eur J Pharmacol 431: 311-314, 2001.

LIU S, LIU YP, YUE DM, LIU GJ: Protease-activated receptor 2 in dorsal root ganglion contributes to peripheral sensitization of bone cancer pain. Eur J Pain 18: 326-337, 2014.

MACFARLANE SR, SEATTER MJ, KANKE T, HUNTER GD, PLEVIN R: Proteinase-activated receptors. Pharmacol Rev 53: 245-282, 2001.

MOLINO M, BARNATHAN ES, NUMEROF R, CLARK J, DREYER M, CUMASHI A, HOXIE JA, SCHECHTER N, WOOLKALIS M, BRASS LF: Interactions of mast cell tryptase with thrombin receptors and PAR-2. J Biol Chem 272: 4043-4049, 1997.

MULE F, BAFFI MC, FALZONE M, CERRA MC: Signal transduction pathways involved in the mechanical responses to protease-activated receptors in rat colon. J Pharmacol Exp Ther 303: 1265-1272, 2002.

NOORBAKHSH F, VERGNOLLE N, HOLLENBERG MD, POWER C: Proteinase-activated receptors in the nervous system. Nat Rev Neurosci 4: 981-990, 2003.

NOORBAKHSH F, TSUTSUI S, VERGNOLLE N, BOVEN LA, SHARIAT N, VODJGANI M, WARREN KG, ANDRADE-GORDON P, HOLLENBERG MD, POWER C: Proteinase-activated receptor 2 modulates neuroinflammation in experimental autoimmune encephalomyelitis and multiple sclerosis. $J$ Exp Med 203: 425-435, 2006.

NYSTEDT S, EMILSSON K, WAHLESTEDT C, SUNDELIN J: Molecular cloning of a potential proteinase activated receptor. Proc Natl Acad Sci US A 91: 9208-9212, 1994.

NYSTEDT S, LARSSON AK, ABERG H, SUNDELIN J: The mouse proteinase-activated receptor-2 cDNA and gene. Molecular cloning and functional expression. J Biol Chem 270: 5950-5955, 1995.

NYSTEDT S, RAMAKRISHNAN V, SUNDELIN J: The proteinase-activated receptor 2 is induced by inflammatory mediators in human endothelial cells. Comparison with the thrombin receptor. J Biol Chem 271: 14910-14915, 1996.

PENG C, ARON L, KLEIN R, LI M, WURST W, PRAKASH N, LE W: Pitx3 is a critical mediator of GDNF-induced BDNF expression in nigrostriatal dopaminergic neurons. J Neurosci 31: 12802-12815, 2011.

POOLE DP, AMADESI S, VELDHUIS NA, ABOGADIE FC, LIEU T, DARBY W, LIEDTKE W, LEW MJ, MCINTYRE P, BUNNETT NW: Protease-activated receptor 2 (PAR2) protein and transient receptor potential vanilloid 4 (TRPV4) protein coupling is required for sustained inflammatory signaling. $J$ Biol Chem 288 : 5790-5802, 2013. 
REED DE, BARAJAS-LOPEZ C, COTTRELL G, VELAZQUEZ-ROCHA S, DERY O, GRADY EF, BUNNETT NW, VANNER SJ: Mast cell tryptase and proteinase-activated receptor 2 induce hyperexcitability of guinea-pig submucosal neurons. J Physiol 547: 531-542, 2003.

ROTHMEIER AS, RUF W: Protease-activated receptor 2 signaling in inflammation. Semin Immunopathol 34: 133-149, 2012.

SAIFEDDINE M, AL-ANI B, CHENG CH, WANG L, HOLLENBERG MD: Rat proteinase-activated receptor-2 (PAR-2): cDNA sequence and activity of receptor-derived peptides in gastric and vascular tissue. $\mathrm{Br} J$ Pharmacol 118: 521-530, 1996.

SAWADA K, NISHIBORI M, NAKAYA N, WANG Z, SAEKI K: Purification and characterization of a trypsin-like serine proteinase from rat brain slices that degrades laminin and type IV collagen and stimulates proteaseactivated receptor-2. J Neurochem 74: 1731-1738, 2000.

SEATTER MJ, DRUMMOND R, KANKE T, MACFARLANE SR, HOLLENBERG MD, PLEVIN R: The role of the C-terminal tail in protease-activated receptor-2-mediated $\mathrm{Ca}^{2+}$ signalling, proline-rich tyrosine kinase-2 activation, and mitogen-activated protein kinase activity. Cell Signal 16: 21-29, 2004.

SEELIGER S, DERIAN CK, VERGNOLLE N, BUNNETT NW, NAWROTH R, SCHMELZ M, VON DER WEID PY, BUDDENKOTTE J, SUNDERKOTTER C, METZE D, ANDRADE-GORDON P, HARMS E, VESTWEBER D, LUGER TA, STEINHOFF M: Proinflammatory role of proteinase-activated receptor-2 in humans and mice during cutaneous inflammation in vivo. FASEB J 17: 1871-1885, 2003.

SHIKAMOTO Y, MORITA T: Expression of factor X in both the rat brain and cells of the central nervous system. FEBS Lett 463: 387-389, 1999.

SPICAROVA D, PALECEK J: The role of spinal cord vanilloid (TRPV1) receptors in pain modulation. Physiol Res $\mathbf{5 7}$ (Suppl 3): S69-S77, 2008.

SPICAROVA D, PALECEK J: The role of the TRPV1 endogenous agonist N-oleoyldopamine in modulation of nociceptive signaling at the spinal cord level. J Neurophysiol 102: 234-243, 2009.

SPICAROVA D, ADAMEK P, KALYNOVSKA N, MROZKOVA P, PALECEK J: TRPV1 receptor inhibition decreases CCL2-induced hyperalgesia. Neuropharmacology 81: 75-84, 2014a.

SPICAROVA D, NERANDZIC V, PALECEK J: Update on the role of spinal cord TRPV1 receptors in pain modulation. Physiol Res 63 (Suppl 1): S225-S236, 2014b.

STEAD RH, TOMIOKA M, QUINONEZ G, SIMON GT, FELTEN SY, BIENENSTOCK J: Intestinal mucosal mast cells in normal and nematode-infected rat intestines are in intimate contact with peptidergic nerves. Proc Natl Acad Sci U S A 84: 2975-2979, 1987.

STEINHOFF M, VERGNOLLE N, YOUNG SH, TOGNETTO M, AMADESI S, ENNES HS, TREVISANI M, HOLLENBERG MD, WALLACE JL, CAUGHEY GH, MITCHELL SE, WILLIAMS LM, GEPPETTI P, MAYER EA, BUNNETT NW: Agonists of proteinase-activated receptor 2 induce inflammation by a neurogenic mechanism. Nat Med 6: 151-158, 2000.

STEINHOFF M, NEISIUS U, IKOMA A, FARTASCH M, HEYER G, SKOV PS, LUGER TA, SCHMELZ M: Proteinase-activated receptor-2 mediates itch: a novel pathway for pruritus in human skin. $J$ Neurosci 23: 6176-6180, 2003.

STRIGGOW F, RIEK-BURCHARDT M, KIESEL A, SCHMIDT W, HENRICH-NOACK P, BREDER J, KRUG M, REYMANN KG, REISER G: Four different types of protease-activated receptors are widely expressed in the brain and are up-regulated in hippocampus by severe ischemia. Eur J Neurosci 14: 595-608, 2001.

SUEN JY, GARDINER B, GRIMMOND S, FAIRLIE DP: Profiling gene expression induced by protease-activated receptor 2 (PAR2) activation in human kidney cells. PLoS One 5: e13809, 2010.

SUEN JY, COTTERELL A, LOHMAN RJ, LIM J, HAN A, YAU MK, LIU L, COOPER MA, VESEY DA, FAIRLIE DP: Pathway-selective antagonism of proteinase activated receptor 2. Br J Pharmacol 171: 4112-4124, 2014.

UCHYTILOVA E, SPICAROVA D, PALECEK J: TRPV1 antagonist attenuates postoperative hypersensitivity by central and peripheral mechanisms. Mol Pain 10: 67, 2014.

VERGNOLLE N: Review article: proteinase-activated receptors - novel signals for gastrointestinal pathophysiology. Aliment Pharmacol Ther 14: 257-266, 2000. 
VERGNOLLE N, HOLLENBERG MD, SHARKEY KA, WALLACE JL: Characterization of the inflammatory response to proteinase-activated receptor-2 (PAR2)-activating peptides in the rat paw. Br J Pharmacol 127: 1083-1090, 1999.

VERGNOLLE N, BUNNETT NW, SHARKEY KA, BRUSSEE V, COMPTON SJ, GRADY EF, CIRINO G, GERARD N, BASBAUM AI, ANDRADE-GORDON P, HOLLENBERG MD, WALLACE JL: Proteinaseactivated receptor-2 and hyperalgesia: a novel pain pathway. Nat Med 7: 821-826, 2001a.

VERGNOLLE N, WALLACE JL, BUNNETT NW, HOLLENBERG MD: Protease-activated receptors in inflammation, neuronal signaling and pain. Trends Pharmacol Sci 22: 146-152, $2001 \mathrm{~b}$.

WANG H, UBL JJ, REISER G: Four subtypes of protease-activated receptors, co-expressed in rat astrocytes, evoke different physiological signaling. Glia 37: 53-63, 2002.

WANG S, DAI Y, FUKUOKA T, YAMANAKA H, KOBAYASHI K, OBATA K, CUI X, TOMINAGA M, NOGUCHI K: Phospholipase $\mathrm{C}$ and protein kinase A mediate bradykinin sensitization of TRPA1: a molecular mechanism of inflammatory pain. Brain 131: 1241-1251, 2008.

WANG Y, KEDEI N, WANG M, WANG QJ, HUPPLER AR, TOTH A, TRAN R, BLUMBERG PM: Interaction between protein kinase Cmu and the vanilloid receptor type 1. J Biol Chem 279: 53674-53682, 2004.

WIEGAND U, CORBACH S, MINN A, KANG J, MULLER-HILL B: Cloning of the cDNA encoding human brain trypsinogen and characterization of its product. Gene 136: 167-175, 1993.

WOOLF CJ, MANNION RJ: Neuropathic pain: aetiology, symptoms, mechanisms, and management. Lancet 353: 1959-1964, 1999.

YUAN H, ZHU X, ZHOU S, CHEN Q, MA X, HE X, TIAN M, SHI X: Role of mast cell activation in inducing microglial cells to release neurotrophin. J Neurosci Res 88: 1348-1354, 2010.

ZHAO P, METCALF M, BUNNETT NW: Biased signaling of protease-activated receptors. Front Endocrinol (Lausanne) 5: 67, 2014. 